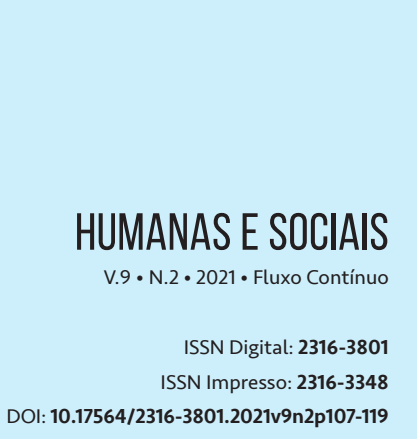

\section{PSYCHOSOCIAL REFLECTIONS OF A QUARANTINE}

REFLEXOS PSICOSSOCIAIS DE UMA QUARENTENA

REFLEJOS PSICOSOCIALES DE UNA CUARENTENA

\section{RESUMO}

0 presente estudo tem por objetivo desenvolver um ensaio de discussão teórica, acerca dos impactos emocionais oriundos do atual cenário de distanciamento social em decorrência da pandemia COVID-19. Daí, intenta-se à uma investigação a respeito dos elementos presentes no referido cenário que possam pré-dizer possíveis indicadores de sofrimento mental. Dada a restrição temporária de liberdade, acaba também, o estado de quarentena, por suprimir a autonomia do indivíduo, ao mesmo tempo em que lhe confere, um profundo sentimento de impotência diante da própria condição. 0 status socioeconômico; o acesso a tecnologias informativas e redes sociais; a disponibilidade de suprimentos médicos e de higiene; a capacidade dos sistemas de saúde; os recursos psíquicos individuais relacionados a resiliência; bem como a pré-existência de comorbidades mentais são apenas alguns dos fatores preditores ou de risco para quadros severos de sofrimento mental em decorrência dessa quarentena.

\section{PALAVRAS-CHAVE}

Saúde Mental. Coronavírus. Isolamento Social. Quarentena. Saúde Pública. 


\section{ABSTRACT}

The present study aims to develop a theoretical discussion essay, to discuss the emotional impacts arising from the current scenario of social distance due to the COVID-19 pandemic. Hence, an attempt is made to investigate the elements present in the aforementioned scenario that may pre-say possible indicators of mental suffering. Given the temporary restriction of freedom, the quarantine state also ends, by suppressing the individual's autonomy, at the same time that it confers on him, a deep feeling of impotence in the face of his condition. Socioeconomic status; access to information technologies and social networks; the availability of medical and hygiene supplies; the capacity of health systems; the individual psychic resources related to resilience; as well as the pre-existence of mental comorbidities are just some of the predictors or risk factors for severe mental suffering due to this quarantine.

\section{KEYWORDS}

Mental health; Coronavirus; Social isolation; Quarantine; Public health.

\section{RESUMEN}

El presente estudio tiene como objetivo desarrollar un ensayo de discusión teórica, con el propósito de discutir sobre los impactos emocionales que surgen del escenario actual de distanciamiento social debido a la pandemia de COVID-19. Por lo tanto, se hace un intento de investigar los elementos presentes en el escenario mencionado que pueden predecir posibles indicadores de sufrimiento mental. Dada la restricción temporal de la libertad, el estado de cuarentena también termina, al suprimir la autonomía del individuo, al mismo tiempo que le confiere, un profundo sentimiento de impotencia frente a su propia condición. Estatus socioeconómico; acceso a tecnologías de la información y redes sociales; la disponibilidad de suministros médicos y de higiene; la capacidad de los sistemas de salud; los recursos psíquicos individuales relacionados con la resiliencia; así como la preexistencia de comorbilidades mentales son solo algunos de los predictores o factores de riesgo de sufrimiento mental severo debido a esta cuarentena.

\section{PALABRAS CLAVE}

Salud mental; Coronavirus; Aislamiento social; Cuarentena; Salud pública. 


\section{INTRODUCTION}

In December 2019, an exponential increase in unexplained pneumonia cases had been noticed in Wuhan, a Chinese city of more than 11 million inhabitants located in Hubei province. Similar cases quickly spread to neighboring cities and countries, prompting the local government to respond quickly (LI et al., 2020; WU; McGOOGAN, 2020). At the same time, two relevant factors were included; (1) a performance following the guideline No. 1 issued by the National Health Commission of the People's Republic of China that framed the modality of pneumonia from the new coronavirus as an infectious disease in those of "category B", and, listed the measures for its control, combat and prevention in those of "category A"; and (2) the decision to close the city of Wuhan and to declare national public health emergency in that same location, and in other locations across China (CHINA CDC, 2020; LI et al., 2020).

A few months later, on 06/10/2020, epidemiological reports show that 212 countries or territories have at least 1 confirmed case of Covid-19. In total, there are already more than 7.145 .000 official cases of infected people and 408.035 cases of people killed due to COVID-19 (WHO, 2020a). Major outbreaks of COVID-19, some with no known or traceable origin, are in full expansion in North and South America. In African and Central American countries, the cases have already reached relevant proportions. The prognosis is, to say the least, worrying. On 11 March, the Director-General of the World Health Organization (WHO) classified the situation of COVID-19 as pandemic, proving that the predictions and events of late 2019 and early 2020 were just the tip of the iceberg (WHO, 2020b ).

To the point that, in mid-March, new epicenters of the virus spread, as in Iran, Spain, Italy, and the United States, containment measures were also intensified. Several countries have adopted quite severe measures, such as restrictions on urban and interurban mobility; cancellation of events with crowds of people; closing borders with neighboring countries; reduction of the period of activity, or even, total closing of the trade (lockdown); establishment of penalties for those who break the quarantine rules; among other measures. The new maxim of health systems on a world scale appears to be: for extreme cases, drastic measures (WILDER-SMITH; CHIEM; LEE, 2020).

Several studies demonstrate that psychic problems are present both in professionals and in patients who survive major epidemics (LEE et al., 2007). After the end of the SARS (Severe Acute Respiratory Syndrome) epidemic, for example, the presence of severe post-traumatic stress disorder (PTSD), as well as intense and recurrent depressive episodes (MAK et al., 2009). The same seems to be true for people who were infected during the MERS (Middle East Respiratory Syndrome) epidemic (HUANG; ZHAO, 2020). Given this scenario, everything seems to indicate problems, in the short, medium, and long term, concerning the presence of characters of mental suffering due to the current pandemic episode of COVID-19.

\section{METHOD}

Given all of the above, the present study attempts to construct a theoretical discussion essay based on studies already published, with the aim of pointing out the possible emotional impacts and psychological repercussions arising from the current outbreak scenario of COVID-19. As a guiding question we 
have: What elements are present in the current epidemic scenario that can pre-tell potential indicators of mental illness and, what lessons can be learned from similar experiences in the past?

\section{RESULTS AND DISCUSSION}

\subsection{LIVED EXPERIENCES AND LESSONS LEARNED: WHAT DO PAST EPIDEMICS HAVE TO TEACH US?}

According to Mak et al (2009, p. 1), the Severe Acute Respiratory Syndrome (SARS) was the first type of infectious disease to have a massive outbreak of spread and contagion in the 21st century, however, the authors warned: "This outbreak is unlikely to be the last". As observed today, there would be predictability on their words. Very quickly, the disease spread to more than 30 countries, reaching over 8000 reported cases that resulted in approximately 774 deaths (WHO, 2003).

In this same study, Mak et al (2009) argue for the existence of a strong tendency for the development of psychic comorbidities on the part of patients who were hospitalized due to SARS. Posttraumatic Stress Disorder (PTSD), for example, was found in $47.8 \%$ of all patients surveyed, and even after 30 months after the outbreak ended, $25.6 \%$ of initial patients were not yet free from it. Another finding occurred concerning depressive disorders, which came to prevail in $46.6 \%$ of the subjects surveyed. Other comorbidities have also been reported, such as Agoraphobia, Panic Disorder, Social Phobia, and Generalized Anxiety Disorder.

Another study (SU et al., 2007) compared, during 4 weeks, the behavior of 102 professionals, among those who actively participated in the action against SARS, and those who worked in the cardiological and neurological sectors at the same time and place. The results were that $38.55 \%$ of the professionals who worked directly in SARS had a prevalence of depressive symptoms, compared to $0 \%$ of those who worked in the cardiology sector, and $6.7 \%$ of those who worked in neurology. Regarding the prevalence of PTSD, there is $34 \%$ for those who worked in SARS, and $11.8 \%$ of those who worked in cardiology and $26.7 \%$ in neurology.

The occupational and psychological effects, facing professionals who worked in hospitals to contain the SARS outbreak is the focus of the study published by Maunder et al. (2006). In it, there was a prevalence of: Burnout in $30.4 \%$ of them; high degree of psychological stress in $44.9 \%$; and PTSD by $13.8 \%$. The research was done in Toronto and Hamilton (Canada). Many of these professionals also manifested, as a consequence of contact with SARS patients, a permanent reduction in face-to-face contact with new patients, a decrease in the workload, an increase in the use of cigarettes or alcoholic beverages, as well as at least 4 shifts due to stress or illness, since the epidemic ended (MAUNDER et al., 2006).

In general, epidemic scenarios tend to expose themselves as a mental burden, both for the general public, who watches the occurrence of the phenomenon and for professionals working in care, in health care and surveillance (MAK et al., 2009; MAUNDER et al., 2006; SU et al., 2007; TSENG; CHEN; CHOU, 2005). These professionals are, mutually with patients who overcome the disease, the people most likely to manifest mental disorders and pathologies as a result of such scenarios (MAK et al., 2009). 
Stigmatization and discrimination also seem to be a problem for patients who survive contagious diseases, such factors contribute to these people experiencing a double degree of victimization because at the time they are victims of the disease and its symptoms they are also victims of discriminatory conducts (CORRIGAN; NIEWEGLOWSKI, 2019).

The SARS epidemic, for example, taught the Chinese administration that investing in preparations and institutional competence can bear fruit. A few months ago, a rapid Chinese intervention prevented the virus from spreading further. Only to provide an idea, in the SARS crisis it took 3 months, 300 cases, and 5 deaths to notify the WHO about the disease, as far as COVID-19 was concerned, 23 days, 27 cases, and no deaths were enough. This measure made it possible, for example, to the WHO, to issue a global alert just 52 days after the notification of the 1st confirmed case, at the time of the SARS outbreak, that same alert occurred after 4 months of the 1st case (WU; McGOOGAN, 2020).

As for the repercussions and psychological problems arising from the SARS epidemic, the literature teaches that the adequate provision of training, as well as the presence of moral support and physical protection, are among factors that motivate more positive results in the face of health professionals working in the situation outbreak. Anticipating the effects of future outbreaks and epidemics from lessons from the past seems to be an important asset in the development of resilience on the part of professionals who will be involved in these new situations (TSENG; CHEN; CHOU, 2005).

\subsection{COVID-19 - EMOTIONAL IMPACTS AND PSYCHOLOGICAL REPERCUSSIONS: WHAT CAN BE DONE?}

Studies that prove the presence, as well as the severity of psychological disorders that emerge coupled with epidemic or outbreak scenarios, are therefore vast, and in general, corroborate the fact that such phenomena cause serious catastrophes in terms of mental health (MAUNDER et al., 2006; SU et al., 2007; MAK et al., 2009; SHULTZ; BAINGANA; NERIA, 2015 CHEN et al., 2020; HUANG; ZHAO, 2020). Quarantine situations due to epidemic outbreaks have been seen as an attitude of protection and regeneration to the infected individual (in social isolation) and society when the latter finds itself in a situation of social distance (SANTOS, 2014).

The regenerative potential of these forms of social withdrawal has been accepted, in recent centuries, combined with the ideas of protection and security. However, at the same time that they have curative nuances, "these are ostensive actions that, once triggered during the period of illness duration, send people to the state of extreme vulnerability, whose right is reduced to naked life" (SANTOS, 2014 p. 70).

Through the interdiction and the temporary restriction of freedom, a quarantine state also ends, by suppressing the individual's autonomy at the same time that it confers on him, a deep feeling of impotence in the face of his condition. In the case of infected patients, the victimization condition is enhanced: one suffers due to the symptomatic condition of the disease; the feeling of abandonment due to social isolation, which generates feelings of helplessness; and yet, for the guilt that is vehemently imputed to him, as if he were " morally responsible "for having acquired the condition of illness.

Sometimes, emotional responses to outbreak situations do not necessarily match the severity or lethality of the event itself but fluctuate according to a complex interplay of factors, such as the rate of contagion; media coverage of the disease and its processes; the presence and intensity of measures 
to mitigate or suppress social contact; the amount of official information available; the availability of medical and hygiene supplies; among others (SHULTZ et al., 2015).

The construction of the mental image about an epidemic is an influencing factor given the prevalence of mental comorbidities that will result from such an event (STOUT VILLEGAS; JENNINGS, 2004), this means, for the media, and for those who carry out informational tasks (official communications, transmissions via the Internet, prevention booklets, postings on social networks etc.), an even greater responsibility concerning an ethical, responsible and concerned informational attitude towards the common good.

Often, it is in the face of such hermeneutical tasks that new understandings are created (GADAMER, 1997). And through this relationship of dialogue between subjects (nurse-patient, media-audience, citizen-state, teacher-student, etc.) new meanings will be created (DELUQUE JÚNIOR; COSTA, 2020; RILLO, 2015). It is expected, of course, that they are humanized and reliable to the reality in which people find themselves. In addition to contributing to the reduction of anxiety, a typical characteristic of outbreak situations, adequate information can build a protective and preventive attitude, which seems to be the focus of combating these epidemics, and in particular, COVID-19.

First, in order to mitigate the emotional impacts arising from social isolation and the widespread change in routine, the governmental attitude of suppressing or mitigating social contact must take place in a way that one can understand the motivations behind such measures if otherwise, it would be just unjustified coercion.

Awareness, as well as information, still seems to be quite effective measures for the maintenance of mental well-being, and, at the same time, for the prevention of new contagions. Given this, attitudes from some government officials and ministers are welcomed, which in the current scenario come to the public to announce, explain and justify measures ranging from awareness of hygiene rules to the closing of shops and decree of curfews.

Although social isolation plays a fundamental role in epidemic control, its consequences concerning subjectivities, both in patients and in the general public, have highly variable characteristics (SHULTZ et al., 2015; HUANG; ZHAO, 2020). This equation includes socioeconomic status; access to appropriate medical treatments and supplies; availability of family support; the existence of a priori employment relationship, as well as subjective issues inherent to resilience, that is, the personality of the individual affected by the disease and those who are in preventive physical and social distance.

Another characteristic that differs from the scenario in which COVID-19 has spread, from other similar episodes, is the massive presence of the use of technologies that allow the spread of information about the epidemic practically in real-time. Such resources are, above all, positive, and act to mitigate the effects of social distance to the extent that they allow activities such as teleworking, teleducation, teleconsultations with various professionals, as well as the possibility of video contact with family and friends.

However, the use of such technologies also brings negative factors such as the triggering of fake news, and the dissemination of alarmist attitudes and information, phenomena which, end up contributing to the increase of stressors in the populations they are destined, taking them unprepared. On 
this track, the most fragile, psychologically speaking, are the most vulnerable, and therefore, those who suffer the most.

In this context, the practice of psychology deserves to be rethought and adapted to such extraordinary events, and given the uncertainties that emerge in these new times, alternative psychotherapeutic practices deserve to be considered. One of them is the psychological assistance via telephone, whose origin goes back to the 50s (GODLESKI et al., 2008), where it achieved significant success in combating and preventing suicide (SCHARFF, 2012). Online therapy, in turn, has already been customary in some countries such as the United States, Australia, and the United Kingdom (PIETA; GOMES, 2014).

Social media platforms present themselves as a relevant resource in terms of information sharing. Just to provide an idea, more than 2.9 billion people use them regularly, and they can even be used to support emergency responses in crises, as well as to foster resilience attitudes and technical preparation in the face of these same situations (MERCHANT; LURIE, 2020). In the context of the current pandemic of COVID-19, what is observed, fortunately, are quite positive attitudes on the part of the teams managing these platforms.

Such attitudes lead users, in a widespread manner, to official and reliable sources of information, which can, through the construction of new and adequate understandings about the epidemiological context, contribute to the reduction of anxiety levels. Such measures, combined with combating what the WHO classifies as an "epidemic of false information" (WHO, 2020c), contribute abundantly to the prevention of panic attitudes and feelings of psychological confusion (MERCHANT; LURIE, 2020).

Merchant and Lurie (2020) argue that the passage through social distance will be particularly challenging for people who are already disadvantaged, such as older people, with low socioeconomic status or housing insecurity, individuals who deal with chronic illnesses or disabilities, and individuals without documents or who reside in the country illegally. Social networks can be used to increase awareness of the needs of these populations and, thus, contribute to the development of new methods that enable communities to mobilize physical and economic resources, and psychological support for these people.

Also, psychological support 'first aid' can be used through chatbots (artificial intelligence programs that have the ability to engage in brief dialogues with chat platform users), when using artificial intelligence to analyze patterns of interaction of millions of users on the COVID-19 pandemic, and thus better understand the most critical needs of each of these people (VAIDYAM et al., 2019). Once before-mentioned demands are identified, one can even undertake, automatically, in the direction of referrals to the competent authorities and organizations.

Another point that demands reflection is related to the topic of economic activity in times of epidemic. It is worth remembering that the world economy already seemed to be heading for a possible recession even before COVID-19 spread (REUTERS, 2020). The widespread condition of COVID-19 has caused world markets to collapse, despite the creation of economic stimulus measures of proportions never before seen in history. Faced with this scenario, many people have been dismissed from their regular jobs, in addition to those self-employed professionals who, without fixed income, observe anesthetized to the vertiginous drop in their income (CHEN et al., 2020). 
The phenomenon of loss of socioeconomic status is therefore a relevant risk factor for the development of mental illness, and it can be related to the increase in suicide rates. In the meantime, a new category of vulnerable people is emerging: that of those who have lost a lot in terms of purchasing power (SILVA et al., 2020).

Knowing that the health status of a given population is also shaped by their socioeconomic conditions, the occurrence of financial crises, whatever their origins, profoundly and significantly affects the mental health of people who are vulnerable to them (SILVA et al., 2020 ). The emergence of such events leads to negative conditions, such as unemployment, the increase in debts, and the loss of purchasing power.

As a result, the need to resort to countermeasures, such as the release of low-interest credit for micro, small and medium-sized companies, relief from the tax burden, awareness of the real epidemiological situation, the creation of protective measures and employment incentives, as well as promoting the creation of support and protection policies for self-employed workers or those who have already lost their jobs (TSENG et al., 2005).

In general, studies on this topic corroborate the need, inherent in mental health care and care services, to become particularly attentive to the populations that suffer most in times of crisis. It is crucial, however, to keep the medical and psychological support services available to these people accessible, universal, and tangible to be paid for. Prevention also seems to be a good way, and at this point, social reforms aimed at the economic empowerment of less favored populations are essential to minimize, at least in theory, social inequalities in times of economic crisis.

\section{FINAL CONSIDERATIONS}

In an attitude of openness towards the possibilities underlying the theme, it can be said that proceeding with any discourse, which is considered definitive regarding the emotional impacts brought by the current scenario of COVID-19 is a task that is little sustained. As in any event that emerged in the phenomenality of everyday's life, this one also has variables and particularities that are quite cross-linked.

Socioeconomic status; access to information technologies and social networks; the availability of medical and hygiene supplies; the capacity of the health system, with particular attention to the number of beds and mechanical respirators; the individual psychic resources related to resilience; as well as the predisposition or pre-existence of mental comorbidities are just a few predictive or risk factors for mental distress due to the COVID-19 pandemic.

It is an equation whose unknowns are infinite, therefore, the present study is limited to pointing out the risks inherent to the emergence of problems and conditions of psychological suffering that may arise from the other alterities existing in the social context that is presented here, concerning the effects of measures that mitigate individual freedoms, such as the isolation imposed on infected people, quarantine measures inherent to people with symptoms or suspicion of COVID-19, as well as with the social distancing policies that it has been taking increasingly restrictive designs around the world. 
For this, the present essay used as a basis, first, studies that were dedicated to demonstrate the existence of these interrelationships in past experiences, as in the SARS and H1N1 outbreaks. Among mental disorders and their indicators, it was possible to verify the incidence or prevalence of depressive disorders; PTSD; anxiety disorders; propensity for suicide; problems related to alcoholism and substance abuse; agoraphobia; panic disorder; social phobia; insomnia; burnout, among many others.

Nesse sentido, a responsabilidade que se faz inerente aos agentes formadores opinião atuantes nos referidos cenários se potencializa. Coberturas jornalísticas devem passar a atuar de maneira mais ponderada, e sempre buscando uma gramática mínima entre, retratar a severidade do quadro em questão e fomentar atitudes de tranquilidade social ao se operar com o mínimo de alarmismo possível.

The same applies to other opinion-forming agents in full swing in times of digital information. Social media platforms can help to propagate adequate information and proceed with preventive attitudes regarding the identification of risk factors for mental illness in its users. As for the various existing communicators (YouTubers, digital influencers, TV presenters, columnists, etc.), the message is the same: to operate with a sense of humanity and in favor of harmony, prevention, and social peace.

Finally, those who are more subject to contagion, professionals working in health care, should not be left out. It is on them that the mental burden presents itself with more severe and harmful nuances (MAUNDER et al., 2006). Support, prevention, and reception strategies must be thought out and put into practice so that these people are not affected by mental disorders and illnesses due to work overload and responsibilities.

\section{REFERENCES}

Bedford, J. et al. COVID-19: towards controlling of a pandemic. The Lancet, Published online March 16, 2020. doi:10.1016/S0140-6736(20)30673-5

Chen, Q.; Liang, M.; Li, Y.; Guo, J.; Fei, D.; Wang, L.; Wang, J. Mental health care for medical staff in China during the COVID-19 outbreak. The Lancet Psychiatry, 2020. DOI: 10.1016/S22150366(20)30078-X.

CHINA CDC. Chinese Center for Disease Control and Prevention (China CDC). chinacdc.cn. 2020. Available in: http://www.chinacdc.cn/en/COVID19/. Accessed: mar. 9, 2020.

Clement, J. Number of global social media users 2010-2021. Statista website. Available in: https:// www.statista.com/statistics/278414/number-of-worldwide-social-network-users/. Accessed: mar. 16, 2020.

Corrigan, P. W.; Nieweglowski, K. How does familiarity impact the stigma of mental illness? Clinical psychology review, v. 70, p. 40-50, jun. 2019. DOI: 10.1016/j.cpr.2019.02.001. 
DELUQUE JÚNIOR, Romano; COSTA, Márcio Luís . Mídia, Preconceito e Adoecimento Mental: Contribuições da Hermenêutica Gadameriana-Um Ensaio a partir da obra “Verdade e Método"de HansGeorg Gadamer. Revista Comunicação, Cultura e Sociedade, v. 10, n. 2, p. 51-78, 2020. Available in: https://periodicos.unemat.br/index.php/ccs/article/viewFile/4430/35676. Accessed: mar. 16, 2020.

Fisher, D.; Wilder-Smith, A. The global community needs to swiftly ramp up the response to contain COVID-19. Correspondence, 2020. DOI: 10.1016/S0140-6736(20)30679-6.

Gadamer, H. G. Verdade e método. Tradução Flávio Paulo Meurer. 3. ed. Petrópolis, RJ: Vozes, 1997. (Originalmente publicado em 1960).

Godleski, L.; Nieves, E.; Darkins, A.; Lehmann, L. VA telelemental health: Suicide assessment. Behavioral Sciences and the Law, v. 26, p. 271-286, 2008. DOI: 10.1002/bsl.811

Huang, Y.; Zhao, N. Generalized anxiety disorder, depressive symptoms and sleep quality during COVID-19 epidemic in China: a web-based cross-sectional survey. medRxiv, 2020. DOI: 10.1101/2020.02.19.20025395

Lee, A. M.; Wong, J. G.; McAlonan, G. M.; Cheung, V.; Cheung, C.; Sham, P. C.; Chu, C. M.; Wong, P. C.; Tsang, K.W.; Chua, S. E. Stress and psychological distress among SARS survivors 1 year after the outbreak. Can J Psychiatry, v. 52, p. 233-240, 2007. DOI:10.1177/070674370705200405

Li Q.; Guan X.; Wu P. et al. Early Transmission Dynamics in Wuhan, China, of Novel CoronavirusInfected Pneumonia. N Engl J Med., 2020. DOI:10.1056/NEJMoa2001316

Mak, I. W., Chu, M. C., Pan, P. C., Yiu, M. G., Chan, V. L., Long-term psychiatric morbidities among SARS survivors. Gen Hosp Psychiatry, v. 31, p. 318-326, 2009. DOI: 10.1016/j. genhosppsych.2009.03.001

Maunder, R; Lancee, W. J.; Rourke, S. B.; Hunter, J.; Goldbloom, D. S.; Petryshen, P. M. et al. The experience of the 2003 SARS outbreak as a traumatic stress among frontline healthcare workers in Toronto: lessons learned. In: MCLEAN, A. R.; MAY, R. M.; PATTISON, J.; WEISS, R. A. (ed.). SARS: a case study in emerging infections. Oxford: Oxford University Press. 2005. p. 96-106. DOI: 10.3201/eid1212.060584

Merchant, R. M.; Lurie, N. Social Media and Emergency Preparedness in Response to Novel Coronavirus. JAMA, mar. 23 2020. DOI: 10.1001/jama.2020.4469

Pieta, M. A. M.; Gomes, W. B. Psicoterapia pela Internet: viável ou inviável?. Psicologia: Ciência e Profissão, v. 34, n. 1, p. 18-31, 2014. DOI:10.1590/S1414-98932014000100003 
Reuters. COVID-19: Global economy already in recession. Retrieved from: https://www.nst.com.my/ business/2020/03/576332/covid-19-global-economy-already-recession. Accessed: mar. 20, 2020.

Rillo, A. G. Análisis hermenéutico de la pregunta por la salud. Humanidades Médicas, v. 15, n. 3, p. 401-420, 2015. Retrieved in from: http://scielo.sld.cu/scielo.php?script=sci_arttext\&pid=S1727$81202015000300002 \& \operatorname{lng}=$ es\&tlng=es. Accessed: mar. 22, 2020.

SANTOS, I. A. Conflitos bioéticos na quarentena humana. 2014. 85 f. Dissertação (Mestrado em Bioética) - Universidade de Brasília, Brasília, 2014. Avaiable in: http://bdtd.ibict.br/vufind/Record/ UNB_78767bd3f21b006331e8e9786affb70a. Accessed: mar. 22, 2020.

Scharff, J. F. Clinical issues in analyses over the telephone and the internet. International Journal of Psychoanalysis, v. 93, p. 81-95, 2012. doi:10.1111/j.1745-8315.2011.00548. Accessed: mar. 22, 2020.

Shultz, J. M.; Baingana, F.;. Neria, Y. The 2014 Ebola outbreak and mental health: current status and recommended response. Jama, v. 313, n. 6, p. 567-568, 2015. DOI: 10.1001/jama.2014.17934.

Silva, M.; Resurrección, D. M.; Antunes, A.; Frasquilho, D.; Cardoso, G. Impact of economic crises on mental health care: a systematic review. Epidemiology and psychiatric sciences, v. 29, 2020. DOI: $10.1017 /$ S2045796018000641

STOUT, P. A.; VILLEGAS, J.;JENNINGS, N. A. Images of mental illness in the media: identifying gaps in the research. Schizophrenia bulletin, v. 30, n. 3 p. 543-561, 2004. doi:10.1093/oxfordjournals.schbul.a007099

Su, T. P.; Lien, T. C.; Yang, C. Y.; Su, Y. L.; Wang, J. H.; Tsai, S. L.; Yin, J. C. Prevalence of psychiatric morbidity and psychological adaptation of the nurses in a structured SARS caring unit during outbreak: a prospective and periodic assessment study in Taiwan. J Psychiatr Res., v. 41, p. 119-130, 2007. doi:10.1016/j.jpsychires.200512.006

Tseng, H. C.; Chen, T. F.; Chou, S. M. SARS: Key factors in crisis manage- ment. J Nurs Res., v. 13, p. 58-65. 2005. PubMed PMID: 15977136.

VAIDYAM, Aditya Nrusimha et al. Chatbots and conversational agents in mental health: a review of the psychiatric landscape. The Canadian Journal of Psychiatry, v. 64, n. 7, p. 456-464, 2019. doi:10.1177/0706743719828977.

WHO - World Health Organization. Coronavirus disease (COVID-2019) situation reports. Situation report-66. March 26, 2020a. https://www.who.int/docs/default-source/coronaviruse/reports/20200326-sitrep-66-covid-19.pdf?sfvrsn=81b94e61_2. Accessed: mar. 26, 2020. 
WHO - World Health Organization. Novel coronavirus (2019-nCoV): situation report-13.

Published february 2, 2020b. https://www.who.int/docs/default-source/coronaviruse/situationreports/20200202-sitrep-13-ncov-v3.pdf. Accessed: mar. 16, 2020.

WHO - World Health Organization. WHO Virtual press conference on COVID-19. March 11, 2020c. https:// www.who.int/docs/default-source/coronaviruse/transcripts/who-audio-emergencies-coronavirus-pressconference-full-and-final-11mar2020.pdf?sfvrsn=cb432bb3_2. Accessed: mar. 16, 2020.

WHO - World Health Organization. Summary of probable SARS cases with onset of illness from 1

November 2002 to 31 July 2003. Published in march 2004. Retrieved from: http://www.who.int/csr/ sars/country/table2004_04_21/en/;2003. Accessed: mayo 20, 2005

Wilder-Smith, A.; Chiew, C. J.; Lee, V. J. Can we contain the COVID-19 outbreak with the same measures as for SARS? The Lancet Infectious Diseases,2020. DOI: 10.1016/S1473-3099(20)30129-8

Wu, Z.; McGoogan, J. M. Characteristics of and Important Lessons From the Coronavirus Disease 2019 (COVID-19) Outbreak in China: Summary of a Report of 72314 Cases From the Chinese Center for Disease Control and Prevention. JAMA, 2020. DOI: 10.1001/jama.2020.2648 
1 Graduado em Psicologia pela Universidade para o Desenvolvimento do Estado e da Região do Pantanal UNIDERP; Doutorando em Regime de Aluno Especial em Saúde e Desenvolvimento da Região Centro-Oeste pela Universidade Federal do Mato Grosso do Sul - UFMS; Mestrando em Psicologia pela Universidade Católica Dom Bosco - UCDB com Bolsa CAPES/PROSUC.

E-mail: romanodeluque@gmail.com

2 Graduado em Filosofia, Universidade Católica Dom Bosco; Pós-Graduando em Psicologia Positiva pela Faculdade IBC; Graduando em Nutrição pela Faculdade Mato Grosso do Sul - FACSUL e em Psicologia pela Universidade para o Desenvolvimento do Estado e da Região do Pantanal UNIDERP; Pesquisador em temas de saúde e longevidade masculina. E-mail: cmarton23@gmail.com

3 Doutora em Saúde e Desenvolvimento da Região CentroOeste pela Universidade Federal de Mato Grosso do Sul - UFMS; Mestra em Biotecnologia Aplicada à Saúde pela Universidade Católica Dom Bosco - UCDB; Professora do Curso de Nutrição do Centro Universitário UNIGRAN/CAPITAL e da Faculdade Mato Grosso do Sul - FACSUL.

E-mail: mariane-nutricionista@hotmail.com

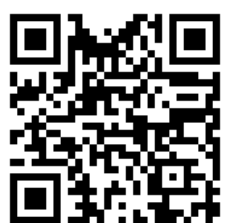

A autenticidade desse artigo pode ser conferida no site https://periodicos. set.edu.br

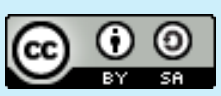

Este artigo é licenciado na modalidade acesso abertosob a Atribuição-Compartilhalgual CC BY-SA

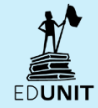

